\title{
Information and Media Literacy and "Cloud" Technologies in Training of Higher Education Applicants: The Sustainable Development Paradigm
}

\author{
Nataliia Kolesnyk ${ }^{1}$, Snizhana Kubrak ${ }^{2, *}$, Tetiana Yavorska ${ }^{3}$, Svitlana Vitvytska ${ }^{4}$ \\ ${ }^{1}$ Department of Artistic Disciplines and Teaching Methods, Zhytomyr Ivan Franko State University (ZSU), Ukraine \\ ${ }^{2}$ Department of Foreign Languages, Zhytomyr National Agroecological University (ZhNAEU), Ukraine \\ ${ }^{3}$ Department of Theoretical and Methodical Basis of Physical Education and Sport, Zhytomyr Ivan Franko State University (ZSU), \\ Ukraine \\ ${ }^{4}$ Department of Pedagogy, Professional Training and Management of Educational Institutions, Zhytomyr Ivan Franko State \\ University (ZSU), Ukraine
}

Received March 14, 2020; Revised April 24, 2020; Accepted May 3, 2020

Copyright $@ 2020$ by authors, all rights reserved. Authors agree that this article remains permanently open access under the terms of the Creative Commons Attribution License 4.0 International License

\begin{abstract}
The authors developed a structural model of formation of information and media literacy of higher education applicants and the use of "cloud" technologies in the educational process of sustainable development. The researchers analyse the levels of formation of such literacy of higher education applicants in the process of sustainable development (cognitive and informative, constructive and search, creative and productive levels). The authors noted the effectiveness of the designed model. Positive dynamics of the development of indicators of the mobility under research are demonstrated on the basis of comparative analysis of the generalized obtained data before and after the experiment. The article presents the methodology of interaction of information and media literacy and "cloud" technologies in the educational process. Summarizing the results of the experimental research using statistical and comparative methods of analysis, made it possible to trace the dynamics of quantitative and qualitative changes in the basic structural components, in particular in the indicators of the interaction of information and media literacy and "cloud" technologies in the educational process of sustainable development of higher education applicants. The results of the research indicate the significant increase in all indicators.
\end{abstract}

Keywords Information and Media Literacy, "Cloud" Technologies, Training of Higher Education Applicants, Sustainable Development, “Cloud” Environment, Internet Resources

\section{Introduction}

Modern information society needs the informatization of higher education, the purpose of which is the rationalization of intellectual activity through the use of new information technologies, the radical improvement of the efficiency and quality of training of higher education applicants with a new type of thinking that meets the requirements of the society. It is worth noting that the dominant space of the past centuries was physical. In the twentieth century, information became dominant, and lately, in the twenty-first century, such a space would become virtual. On average, modern person spends over eight or even more hours a day in front of different types of screens (smartphone, iPad, computer, TV). The modernization of higher education within the Bologna system led to an increase of the role of information and media training for higher education applicants. They are to design the educational environment with the help of modern information and communication, computer, web, virtual, and "cloud" technologies. The development of modern technologies and the rapid changes in this field needs new requirements for training all higher education applicants. Today, humanity has grown up in verbal space. The creation and transfer of knowledge in the information field and media literacy is built on the basis of this space.

Current tendencies of reforming the system of training determine the need to improve its theoretical, methodological and technological base. This framework aims to use e-learning according to the paradigm of sustainable development. While training higher education applicants, the task is to provide educational process with 
high-quality electronic learning tools not only for computers, but also for other modern devices that could be used not only in higher education institutions but also in many other public places.

A common benefit for all users of "cloud" technologies is that you can access the "cloud" not only from your computer or laptop, but also from your netbook, smartphone, tablet and other gadgets, since the main requirement for access is the availability of the Internet. And for the operation of the "cloud" software the capacity of the remote server is used; consumers use programs without installing them. A "cloud" is a centre, server, or network that stores data and applications that connect users over the Internet. It should be noted that thousands of people with access rights can have access to the "cloud" at the same time.

In the aspect of our research, we agree with M. Zhaldak [1] who defined the concept of "cloud technologies" as a set of methods, tools and techniques used for collecting, organizing, storing, processing, transmitting through the network and submitting through the client's program all kinds of messages and data.

\subsection{The Aim}

The aim of this research is to investigate the effectiveness of the model implementation of formation of information and media literacy and the use of "cloud" technologies in the process of training of higher education applicants.

\subsection{Tasks}

1) To develop the structural model of formation of information and media literacy of higher education applicants and the use of "cloud" technologies in educational process of sustainable development.

2) To analyze the levels of formation of information literacy in the process of sustainable development.

3) To test the effectiveness of the developed model in the process of sustainable development by means of "cloud" technologies.

4) To present methodology of interaction of information and media literacy and "cloud" technologies in the educational process of higher education applicants.

\section{Materials and Methods}

\subsection{Participants}

The experimental research was carried out on the basis of Zhytomyr Ivan Franko State University and Zhytomyr National Agroecological University in 2017 - 2019. 422 people participated in the research, among them students 258 people, teachers of the New Ukrainian School - 144 people, lecturers - 20 people. Experimental (EG, $n=211$, 129 students, 72 teachers of NUS, 10 lecturers) and control (CG, n = 211, 129 students, 72 teachers of NUS, 10 lecturers) groups were formed. As a result of experimental research, it is envisaged to carry out a diagnostic test in control and experimental groups to determine the effectiveness of the level of significance of the main indicators of information and media literacy and "cloud" technologies in the educational process of sustainable development of higher education applicants.

\subsection{Research Methods}

A set of modern general scientific methods was used to fulfill the aim and realize the tasks of the research. The experimental research was carried out in several stages using the following research methods: theoretical (analysis, synthesis, generalization, modelling, design, classification, extrapolation and prognostication methods); empirical (online interviewing, questioning, testing, conversation); methods of mathematical statistics (ranking, factor analysis, multivariate analysis of variance, parametric and non-parametric methods of comparison of experimental data using the computer program SPSS (version 13.0), which were allowed to carry out qualitative and quantitative analysis of the results of the experiment; graphic - to illustrate, interpret and compare the results of experimental work in graphical images and tabular forms.

\subsection{Research Procedure}

In the process of organizing the experimental research, the control and experimental groups were identified. The levels of formation of information literacy of higher education applicants are determined as: cognitive and informative, constructive and search, creative and productive. This made it possible to compare the initial and final results of the research, quantitative analysis of the results of the process of implementation and the use of "cloud" technologies with the help of selected complex of diagnostic methods.

Wiloxon's T-test was used in the research. It is a non-parametric statistical test (criterion) used to test differences between two samples of paired or independent measurements on the level of any quantitative trait measured in a continuous or ordinal scale. The criterion is intended to compare indicators measured in two different conditions with the same sample. The Wilcoxon T-Criteria Table of Critical Values was used in our research. It presents values depending on the level of significance.

During the experimental research, a comparative analysis and study of the dynamics of indicators development in the process of sustainable development using the Wilcoxon T-test was made. Statistically significant shifts in the experimental groups were revealed 
in almost all indicators: "Online communication interaction" ( $\left.\mathrm{T}=4,58^{* *}\right)$, "The use of online technologies" $\left(\mathrm{T}=3,92^{* *}\right)$, "Variability of creative potential realization" ( $\mathrm{T}=1.96)$, "Self-understanding" $\left(\mathrm{T}=3,19^{* *}\right)$. Only the indicator "Readiness for self-development of information and communication mobility" ( $\mathrm{T}=-1,86)$ had no statistically significant trends.

The analysis of the results of the research was performed using the O. Smirnov's method. Its essence is in the use of relative frequencies. During the research the authenticity of differences between the indicators of students by means of Stjudent's t-test was determined. The dynamics of indicators in each group was also estimated. The significance for all statistical tests was set at $\mathrm{p}<0.05$.

\subsection{Ethical Approval}

This study complies with the ethical standards of the Act of Ukraine "On Higher Education" No. 1556-VII dated 01.07.2014 and the Letter from the Ministry of Education and Science of Ukraine "On the Academic Plagiarism Prevention” No. 1/11-8681 dated 15.08.2018.

\section{Results and Discussion}

The term "information and media literacy" conceals in itself quite complex content, that is, a concept. It is quite obvious that this semantic complication reflects the new realities that emerge nowadays, the time of information and communication technologies and the dynamic expansion of the important sphere of knowledge in the context of sustainable development.

Even a cursory acquaintance with literary sources testifies to the emergence of new meanings of the concept of the term "literacy". In many sources, "literacy" means not only the ability to read and write, but also the possession of some skills and even knowledge. For example, information literacy is interpreted by $\mathrm{O}$. Gromova as “... the ability to formulate an information need, request, search, select, estimate and process of information, whatever it may be" [2]. Recently, it became necessary to significantly expand the periphery of this concept, and as a result, such complex terms as "Multiple Literacies", "Multimodal Literacy", "Poliliteracy", "Multiliteracy" and finally "Transliteracy" have emerged [3]. As it is noted in Large Ancient Greek Dictionary, that the word "literacy" derived from the Greek $(\delta i \pi \lambda \omega \mu \alpha)$, the original meaning of which was associated with a line, in general, with any written sign [4]. In semiotics, the sign “... means any tangible object, sensibly perceived by the subject, and used to designate, represent, substitute for another object called the value of that sign" [5].

And no matter what the semiotic system is, a person who is able to make sense of these signs can be considered competent. This means that synaptic connections between the drawing of signs and their conceptual content developed and strengthened in his brain. In other words, "literacy" is the ability to perceive the meaning embedded in any text that consists of a set of characters belonging to a particular semiotic sign system. Or, in short, as it was said by S. Ivanov [6] "literacy" is the wielding of a particular semiotic system.

Thus, information and media literacy should be understood as the development of a certain number of semiotic systems that form the basis of media texts language and means of their processing and perception. In the context of this article purpose, it is obvious that literacy levels should not be considered only in relation to its type (computer, media, information, networking, etc.), but in relation to a particular stage of knowledge acquisition. Strategically, the essence of education in a person-centred sense is reduced to an awareness of the value of forming a developed thesaurus. By thesaurus, we mean the set of information relationships, semantic relationships, and finally, the individual emotions. It can be generally argued that the learning process is the process of expanding and restructuring an individual thesaurus. As Michel Montaigne noted, "A well-built brain costs more than a well-filled brain". Nevertheless, we agree with L. Familyarskaya [7], that the thesaurus, as a dynamic system of image-values, is able to induce the internal language and, in the course of its circulation, to generate new knowledge. The developed personal thesaurus is the basis for the formation of the individual's labour potential in the modern labour market.

At the stage of setting a problem, an effective way to visualize it is MindMapping technology, which implements an associative way of thinking. XMind is also very useful here, with a simple interface and wide conceptual capabilities. This software provides the ability to effectively plan the performance of the task, implements a graphical presentation of ideas, through their conceptual organization, allows combining any kind of data (text, numbers, audio, video, sites, etc.).

A clear formulation of the task helps to minimize labour costs at this stage. Here, search is understood as a set of logical and technical operations that have the ultimate purpose of finding documents, information about them, facts, data that meet the customer's request. Search literacy is manifested in the use of appropriate sign systems. So, searching by rubricator means the ability to navigate the search directories, this is a collection of links to other resources of the Internet. Advanced search involves knowing a specific query language based on knowledge of certain rules (sign system). It is useful to create a list of links to problem-oriented Internet resources. At this stage, critical selection is crucial for further data analysis. First of all, their qualitative assessment should be based on such features as the authority and competence of the source, clarity, timeliness, reliability and 
comparability of the data obtained.

In the process of higher education applicants' training, we use a "cloud-oriented" system of learning support. By such a system we mean the fulfilment of didactic goals, which involves the use of "cloud" services and technologies. It provides group collaboration of teachers and applicants, development, management, as well as dissemination of educational materials by providing the subjects of educational process with access to the means of "cloud" technologies.

In the process of sustainable development, we consider "cloud" technology as a paradigm that involves remote processing and data storage. This technology provides the Internet users with access to server computing resources and the use of software as an online service. That is, if you have an Internet connection, you can perform complex calculations, process data using the power of a remote server.

The "cloud" computing architecture includes many "cloud" components that interact with each other through web services - Application Program Interfaces. The concept of "cloud" data processing includes different models of IT service provision: PaaS, SaaS, DaaS, WaaS, CaaS, EaaS [8].

It is useful to use Evernote technology to capture and store data of various types and formats, including site content, to record voice messages, to collect data found during the search process. An effective feature is the synchronization of notes, which allows you to organize work from virtually any device that has access to the Internet. "Cloud" technologies are effective for storing and sharing. It allows users to store their data on servers in the "cloud" and share it with other users on the Internet (Dropbox, Google Drive, Yandex Drive).

It should be reiterated that the process of acquiring new knowledge can be implemented bypassing the stages of data search and arranging. It can be reduced to "appropriation" of knowledge already "packaged" in one or another didactic form. In other words, it is necessary to possess information technologies of search in open educational resources in the form of educational remote courses, trainings, etc. [9].

The result of sustainable development of higher education applicants' training for the formation of higher education information and media literacy and the use of "could" technologies is the acquisition of knowledge about:

- methodological bases for creating e-content using online services;

- the essence and content of the concepts "educational e-environment”, “e-content”, “online community”;

- conditions of modern communication interaction;

- algorithms for organizing training with the use of online services;
- requirements for organization of training using the e-learning environment.

As a result of the training, higher education applicants acquire the ability to:

- develop information and media literacy on the use of "cloud" technologies;

- understand the basic principles of organizing e-learning;

- form own position on the use of e-learning technologies in the practice of using "cloud" technologies;

- apply algorithms of organizing e-learning in the educational process;

- determine the criteria for choosing e-learning methods for own educational practice.

As a result of the studies, higher education applicants become more aware of the e-learning strategy for the technology of using "cloud" environment of educational communication interaction, which provides many opportunities and ways for sustainable development.

It should be noted that the process of organization of training includes a certain list of conditions that contribute to the value of mastering theoretical and practical material, personal awareness of their importance for professional activity, which is an important condition for the successful development of teacher's ICM. These conditions include:

- problematic nature of material presentation that is studied;

- use of active teaching methods: analysis and modelling of specific pedagogical situations (case-study);

- use of self-examination and reflection techniques (sharing diary);

- $\quad$ system of creative (situational) tasks;

- organization of practical activities of teachers for the use of ICT in the educational process.

Criteria for evaluating program effectiveness:

- $\quad$ knowledge of professional opportunities;

- $\quad$ adequate self-esteem;

- $\quad$ positive self-attitude;

- $\quad$ professional confidence;

- $\quad$ ability to analyze and check professional actions;

- satisfaction with the results of the activity.

The main forms of active development of information and communication mobility are: 1) Classroom work (mini-lectures, practical work, presentation of their own works, press conferences, testing, modelling of educational situations, creative work). 2) Independent work (self-study) outside the classroom (analysis of the information on training topic, selection, preparation and registration of independent work within the module, group tasks). Each training module offers topics for self-study, taking into account the initial training of the teacher. To ensure the practical orientation of the teacher's 
independent work, online counselling is provided after studying the theoretical block of each module. Through feedback, the educator learns about the performance of each module. Consultations are possible but not required. The teacher individually plans the time for independent work, mastering the methods of organizing the modern educational process.

An efficient way to learn something is with the help of an e-mail activity, such as a group work or error-correction game. Using e-mail, the teacher can implement differentiated and individualized approaches to learning by sending each student their personal homework on their e-mails. Students can choose topics for communication independently and change the direction of their discussions, since the main purpose in this case is communication, not reproduction of written speech without errors. In fact, it can be adapted to apply almost any kind of language activity [10].

In our research, we used such forms as: graphs, tables, and diagrams that require information literacy, that is, knowledge of sign systems (programs) such as Graph or Excel. More meaningful from the standpoint of the cognition process is infographics as a way of visualizing data. Currently, there are a lot of software tools available. They allow you to make effective and meaningful infographics, such as pictochart, infogram, data visualization, Google public data explorer, and others. Any audio-visual work can be considered as structuring of different frames on the basis of a single, conceptual, artistic concept. Here, information should be understood as data, considered with some semantic essence in mind.

From the point of view of educational technologies, the modular principle of educational process organization significantly changes the structure and the ratio of classroom and extra-classroom load towards the increasing independent work with educational material and e-content. This means the implementation of a set of methods, means for solving specific didactic tasks and particular types of learning activities (mastering new knowledge, repetition, self-control, independent work, focused on updating professional experience), which provides pedagogical communication and informational interaction of teacher and allows to achieve the planned results.

Each of the modules is aimed to active development program of teacher's ICM and is provided with educational and projective, information and reference, and reflexive and monitoring blocks.

The educational and projective block of each training module provides information on the goals, educational tasks of each topic, contains a system of practical work, a brief description of the content of individual types of course activities, recommendations for carrying out independent research work (project topics, studies and methods of their implementation and presentation, etc.).

The information and reference block provides the necessary information, namely: explanations, samples of exercises or tasks, instructions, comments, flow charts for performing individual tasks and reference materials. This block provides the organizational function (contains information about the goals and objectives of the course, justifies the relevance, theoretical and practical relevance, recommendations for the content, Internet resources, and etc.).

The reflexive and monitoring block contains forms and means of control that have both current and final character. The main forms of control are self-assessment tables, projects (they are shown in the educational-projective block), test tasks. The final control is carried out in the form of computer-based testing. The mean for implementing teacher diagnosis (ongoing and final testing in the learning process) is the Google Forms service. Self-control is made by the teacher in the learning process through scheduling tasks in the sharing diary and analysing the effectiveness of their implementation.

"Sharing" is a training vocabulary term and comes from the English word "to share". The purpose of using a sharing diary is to understand inner feelings and internal processes, to analyze and consolidate experience, to set goals for the future and consistent support of the teacher in the development of components of ICM. At each lesson, the professional and personal reflection of the teacher, using sharing diary, involves filling a page, the content of which is aimed at revealing the level of theoretical and methodological mastering of the material of the topic under study. During the training and after the practical tasks, the teacher analyzes self-changes, assesses his own work, the work of the group, and makes recommendations.

During and after the class, teacher/tutor maintains a card-observation of the activities of the participants. Comparison of results, statements of higher education applicants, teacher/tutor observation materials provides an opportunity to track changes and adjust the content of the next lesson. Applied techniques provide an opportunity to create optimal conditions for the effectiveness of the educational process and the development of components of the teacher's ICM.

At the ascertaining stage of the experiment, on the basis of the developed model, the level of readiness of formation of information and media literacy in higher education applicants in the process of sustainable development by means of "cloud" technologies was under research.

The analysis of the results of the research was carried out using the method of O. Smirnov [11]. Its essence is in the use of relative frequencies. The score of each trait was scored on a 12-point scale, where a score of "12" indicated that the trait was formed at the highest level and a score of " 1 " - at the minimum.

For comparative analysis, for each indicator, the total number of points obtained by each of the respondent was 
calculated. Then the relative frequency or proportion of the indicator was determined according to the following rule:

$$
\begin{gathered}
\text { Relative Frequency }= \\
\text { The total number of points received }
\end{gathered}
$$

The maximum possible points

The results obtained were summarized in a general table and presented graphically. The hypothesis of the reliability of the obtained data was tested based on the use of the Student's t-distribution. For example, let us show the hypothesis of the significance of one of the largest differences between the two particles obtained by students' evaluation of such an indicator as "Understanding the flexibility of online communication”.

The average possible error of the difference of the relative particles $\mathrm{p} 1$ and $\mathrm{p} 2$ is determined by the formulas:

$$
\begin{aligned}
& \mathrm{Sp}_{1}=\sqrt{\frac{p_{1}\left(1-p_{1}\right)}{n_{1}}} ; \\
& \mathrm{Sp}_{2}=\sqrt{\frac{p_{2}\left(1-p_{2}\right)}{n_{2}}}
\end{aligned}
$$

We have $\mathrm{p} 1=0.97, \mathrm{p} 2=0.82, \mathrm{n} 1=50, \mathrm{n} 2=54$ :

$$
\begin{aligned}
& \mathrm{Sp}_{1}=\sqrt{\frac{0,97(1-0,97)}{50}}=0,02 ; \\
& \mathrm{Sp}_{2}=\sqrt{\frac{0,82(1-0,82)}{54}}=0,05 ;
\end{aligned}
$$

Hence $\mathrm{t}$ - Student's distribution - will be:

$$
\mathrm{t}=\frac{p_{1}-p_{2}}{\sqrt{S p_{1}^{2}+S p_{2}^{2}}} ;
$$

$$
\mathrm{t}=\frac{0,97-0,82}{\sqrt{0,02^{2}+0,05^{2}}}=\frac{0,15}{0,054}=2,78
$$

According to the Student's table we find that for the number of degrees of freedom $\gamma=N-1=104-1=103$, the value of the coefficient $t_{p r}=2,78$ will be $t_{\text {theor. }}=2,62$ with a probability of $0.01(1 \%)$. Since all other relative frequency differences will be at least 0.15 , the differences in the estimation of all other indicators will be even more significant.

During the experimental work, the authors offered a methodology for interaction of information and media literacy and "cloud" technologies in the educational process of sustainable development of higher education applicants. Generalized results of the research of such interaction are presented in Table 1.

The practical level of work involves the realization of the teacher designing the educational environment, as a medium for professional and personal development, in particular information and communication mobility, the implementation of monitoring the effectiveness of learning.

A comparative analysis of the results allowed identifying certain trends. Based on the above and the results obtained by the level of importance of motives, needs in I and II groups of teachers, it can be concluded that the two most important indicators are considered by both groups: "Understanding the flexibility of online communication” (0.97-0.82); “Ability to analyze photos, logos, symbols, posters, infographics, other visual series through "cloud" technologies" (0,96-0,80); "Variability of creative potential realization" $(0,95-0,78)$; “Ability to think critically" (0.95-0.77). 
Information and Media Literacy and "Cloud" Technologies in

Training of Higher Education Applicants: the Sustainable Development Paradigm

Table 1. Methodology of Interaction of Information and Media Literacy and "Cloud” Technologies in the Educational Process of Sustainable Development of Higher Education Applicants

\begin{tabular}{|c|c|c|c|c|c|c|c|c|c|c|}
\hline \multirow{2}{*}{$\begin{array}{l}\text { No } \\
\mathbf{p} / \mathbf{n}\end{array}$} & \multirow{2}{*}{$\begin{array}{l}\text { Indicators of information and media literacy } \\
\text { and "cloud" technologies in the educational } \\
\text { process of sustainable development of higher } \\
\text { education applicants }\end{array}$} & \multicolumn{3}{|c|}{ I group } & \multicolumn{3}{|c|}{ II group } & \multicolumn{3}{|c|}{ Differences of values } \\
\hline & & $\begin{array}{c}\text { Assessment } \\
\text { results }\end{array}$ & Evaluation & $\begin{array}{c}\text { Average } \\
\text { value }\end{array}$ & $\begin{array}{c}\text { Assessment } \\
\text { results }\end{array}$ & Evaluation & $\begin{array}{c}\text { Average } \\
\text { value }\end{array}$ & $\begin{array}{c}\text { Assessment } \\
\text { results }\end{array}$ & Evaluation & $\begin{array}{c}\text { Average } \\
\text { values }\end{array}$ \\
\hline 1. & $\begin{array}{c}\text { Ability to implement ideas through online } \\
\text { means }\end{array}$ & 0,94 & 0,79 & 0,78 & 0,76 & 0,59 & 0,59 & 0,18 & 0,20 & 0,19 \\
\hline 2. & $\begin{array}{l}\text { Ability to use media for social good in the } \\
\text { context of sustainable development }\end{array}$ & 0,92 & 0,76 & 0,75 & 0,75 & 0,60 & 0,58 & 0,17 & 0,16 & 0,17 \\
\hline 3. & $\begin{array}{c}\text { Ability to analyze photos, logos, symbols, } \\
\text { posters, infographics, other visual series } \\
\text { through "cloud" technologies }\end{array}$ & 0,96 & 0,78 & 0,79 & 0,80 & 0,61 & 0,62 & 0,16 & 0,17 & 0,17 \\
\hline 4. & Ability to critical thinking & 0,95 & 0,80 & 0,79 & 0,77 & 0,62 & 0,60 & 0,18 & 0,18 & 0,19 \\
\hline 5. & $\begin{array}{l}\text { Orientation to emotional intelligence in the } \\
\text { process of sustainable development }\end{array}$ & 0,91 & 0,74 & 0,74 & 0,75 & 0,57 & 0,58 & 0,16 & 0,17 & 0,16 \\
\hline 6. & Ability to see parallels with the present time & 0,88 & 0,70 & 0,71 & 0,72 & 0,54 & 0,56 & 0,16 & 0,16 & 0,15 \\
\hline 7. & $\begin{array}{l}\text { Ability to create "cloud" environment through } \\
\text { the Internet resources }\end{array}$ & 0,90 & 0,73 & 0,74 & 0,73 & 0,57 & 0,58 & 0,17 & 0,16 & 0,16 \\
\hline 8. & $\begin{array}{c}\text { Understanding the flexibility of online } \\
\text { communication }\end{array}$ & 0,97 & 0,81 & 0,81 & 0,82 & 0,64 & 0,64 & 0,15 & 0,17 & 0,17 \\
\hline 9. & $\begin{array}{l}\text { Readiness for self-development of information } \\
\text { and communication mobility }\end{array}$ & 0,85 & 0,70 & 0,70 & 0,68 & 0,62 & 0,64 & 0,17 & 0,18 & 0,16 \\
\hline 10. & Variability of creative potential realization & 0,95 & 0,81 & 0,79 & 0,78 & 0,62 & 0,63 & 0,17 & 0,19 & 0,16 \\
\hline 11. & Ability to use online technologies & 0,84 & 0,74 & 0,75 & 0,65 & 0,58 & 0,57 & 0,19 & 0,16 & 0,18 \\
\hline 12. & $\begin{array}{l}\text { Mastering awareness, communication, } \\
\text { reflexivity in the process of sustainable } \\
\text { development }\end{array}$ & 0,84 & 0,68 & 0,66 & 0,64 & 0,49 & 0,48 & 0,20 & 0,19 & 0,18 \\
\hline & Final score & 0,91 & 0,75 & 0,75 & 0,74 & 0,59 & 0,59 & 0,17 & 0,16 & 0,16 \\
\hline
\end{tabular}


By the level of significance of the presented indicators in I and II group, higher education applicants identified the least significant indicators as "Ability to use online technologies" (0.84-0.65) and "Mastering awareness, communication, reflexivity in the process of sustainable development” (0.84-0.64) (see Fig. 1).

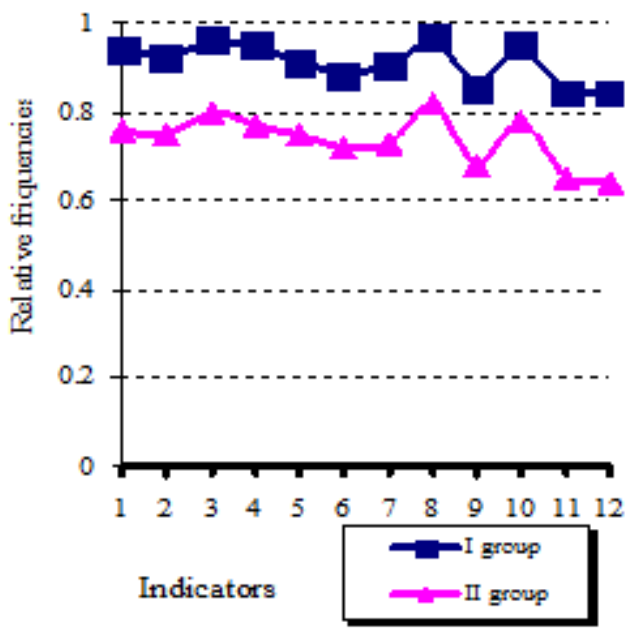

Figure 1. Changing Dynamics of the Level of Significance of the Main Indicators of Information and Media Literacy and "Cloud" Technologies during Educational Process of Sustainable Development of Higher Education Applicants.

Higher education applicants consider indicators such as "Understanding the flexibility of online communication" and "Ability to analyse photos, logos, symbols, posters, infographics and other visual series through "cloud" technologies" to be essential in their professional activities.

During the diagnostic phase of the experiment, according to the survey results of higher education applicants, the following indicators were found to be the most significant: "Ability to implement ideas through online means", "Ability to use media for social good in the context of sustainable development", "Ability to analyse photos, logos, symbols, posters, infographics, other visual series through "cloud" technologies", "Ability to critical thinking", "Orientation to emotional intelligence in the process of sustainable development".

The indicators were analysed in the process of using "cloud" technologies. For this purpose, the authors used a questionnaire, which conducted a survey of higher education applicants.

Thus, the study of information and media literacy and "cloud" technologies in the educational process of sustainable development showed that in its first stage (ascending section) the character of indicators has the same orientation in both experimental and control groups.

At the initial stage of the experimental research, the most important in the results of self-assessment were indicators, which are prevalent in higher education applicants. After the introduction of the developed technology of training of higher education applicants for the use of different technologies in the educational process of sustainable development, the students' indicators have slightly expanded. The dominant indicators became: "Understanding the flexibility of online communication" (0.93); "Ability to implement ideas through online means" (0.92); "Orientation to emotional intelligence in the process of sustainable development" (0.91); "Variability of creative potential realization" $(0,91)$; "Ability to use media for social good in the context of sustainable development" (0.89); "Ability to analyse photos, logos, symbols, posters, infographics, other visual series through "cloud" technologies" (0.87).

However, in the control groups of students, the level of significance of the main indicators remained almost at the initial stage. The "Ability to implement ideas through online means" increased ( 0.58 vs. 0.56 ); "Ability to use media for social good in the context of sustainable development” (0.56 vs. 0.53$)$; “Ability to analyse photos, logos, symbols, posters, infographics, other visual series through "cloud" technologies" ( 0.55 vs. 0.52$)$; “Ability to critical thinking" (0.53 vs. 0.50$)$; “Orientation to emotional intelligence in the process of sustainable development” (0.52 vs 0.50$)$.

The results of the research of the main indicators are shown in Table 2. 
Table 2. Levels of Formation of Interaction between Information and Media Literacy and “Cloud” Technologies in the Educational Process of Sustainable Development of Higher Education Applicants

\begin{tabular}{|c|c|c|c|c|c|c|c|c|}
\hline \multirow{3}{*}{ Indicators } & \multicolumn{4}{|c|}{ Control Groups } & \multicolumn{4}{|c|}{ Experimental Groups } \\
\hline & \multicolumn{2}{|c|}{ Before the Experiment } & \multicolumn{2}{|c|}{ After the Experiment } & \multicolumn{2}{|c|}{ Before the Experiment } & \multicolumn{2}{|c|}{ After the Experiment } \\
\hline & Evaluation & Average value & Evaluation & $\begin{array}{c}\text { Average } \\
\text { value }\end{array}$ & Evaluation & $\begin{array}{c}\text { Average } \\
\text { value }\end{array}$ & Evaluation & $\begin{array}{c}\text { Average } \\
\text { value }\end{array}$ \\
\hline 1 & 0,56 & 0,56 & 0,57 & 0,58 & 0,56 & 0,57 & 0,93 & 0,92 \\
\hline 2 & 0,54 & 0,53 & 0,55 & 0,56 & 0,53 & 0,53 & 0,88 & 0,89 \\
\hline 3 & 0,53 & 0,52 & 0,54 & 0,55 & 0,53 & 0,54 & 0,86 & 0,87 \\
\hline 4 & 0,51 & 0,50 & 0,52 & 0,53 & 0,52 & 0,50 & 0,85 & 0,85 \\
\hline 5 & 0,49 & 0,50 & 0,53 & 0,52 & 0,50 & 0,49 & 0,90 & 0,91 \\
\hline 6 & 0,48 & 0,47 & 0,52 & 0,51 & 0,47 & 0,49 & 0,82 & 0,81 \\
\hline 7 & 0,46 & 0,47 & 0,50 & 0,52 & 0,47 & 0,48 & 0,79 & 0,80 \\
\hline 8 & 0,44 & 0,43 & 0,51 & 0,52 & 0,45 & 0,44 & 0,92 & 0,93 \\
\hline 9 & 0,42 & 0,44 & 0,49 & 0,48 & 0,43 & 0,41 & 0,75 & 0,74 \\
\hline 10 & 0,41 & 0,42 & 0,47 & 0,48 & 0,42 & 0,40 & 0,92 & 0,91 \\
\hline 11 & 0,40 & 0,41 & 0,46 & 0,47 & 0,42 & 0,41 & 0,73 & 0,74 \\
\hline 12 & 0,39 & 0,40 & 0,44 & 0,45 & 0,40 & 0,39 & 0,72 & 0,71 \\
\hline $\begin{array}{l}\text { Final } \\
\text { score }\end{array}$ & 0,47 & 0,47 & 0,50 & 0,55 & 0,48 & 0,47 & 0,84 & 0,84 \\
\hline
\end{tabular}

The results of the research indicate the significant increase in all indicators of the interaction of information and media literacy and "cloud" technologies in the educational process of sustainable development of higher education applicants.

\section{Conclusions}

1. A structural model for the formation of information and media literacy of higher education applicants and the use of "cloud" technologies in the educational process of sustainable development is developed. The model includes conceptual and purpose, procedural and meaningful, evaluative and effective blocks; structural components of the investigated mobility (cognitive and personal, effective and practical, evaluative and reflexive) are also determined; criteria (awareness, communication, reflexivity), indicators (understanding of the flexibility of communication interaction online, self-understanding, readiness for self-development of information and communication mobility, variability of realization of creative potential, use online technologies) were distinguished.

2. During the experimental research, the levels of formation of information and media literacy of higher education applicants in the process of sustainable development (cognitive and informative, constructive and search, creative and productive) were characterized.

3. The effectiveness of the developed model was revealed on the basis of comparative analysis of the generalized data obtained before and after the research, which demonstrates the positive dynamics of the development of the studied mobility indicators. In the experimental and control groups the number of applicants for higher education of creative and productive level increased (EG - from 10,48\% to $17,03 \%$ and CG - from $11,16 \%$ to $13,39 \%$ ), constructive and search level (EG from $36.68 \%$ to $54.15 \%$ and CG - from $42.41 \%$ to $46.43 \%)$ and the number of teachers in cognitive and informative level decreased in all experimental groups (EG - from $52.84 \%$ to $28.82 \%$ and CG - from $46,43 \%$ to $40,18 \%)$. The results clearly indicate a favourable influence of the participation of teachers in the activities, demonstrating positive changes in all components of information and communication mobility of teachers (cognitive and personal, effective and practical, evaluative and reflexive).

4. The methodology of interaction between information and media literacy and "cloud" technologies is presented. Summarizing the results of the experimental research using statistical and comparative methods of analysis, made it possible to trace the dynamics of quantitative and qualitative changes in the basic structural components, in particular in the indicators of the interaction of information and media literacy and "cloud" technologies in the educational process of sustainable development. This allowed discovering positive dynamics. The results of the comparison of indicators showed the presence of a pronounced change in the detected ratios of the control and experimental groups.

\section{Prospects for Further Research}

The study does not highlight all aspects of the paradigm 
of sustainable development in training of higher education applicants in the context of ideas of information and media literacy and the use of "cloud” technologies. In the future, further researches are focused on the development of multimedia technologies, new computer technologies, authoring software applications that work on the WWW-system, Internet in the form of multimedia/hypermedia. The authors plan to create and implement multimedia textbooks into the educational process, which can open up opportunities for updating educational and methodological complexes, as well as the content of teaching and training methods for higher education applicants in the context of European integration processes.

\section{REFERENCES}

[1] M. Zhaldak Problemy informatyzatsiyi navchal'noho protsesu v serednikh i vyshchykh navchal'nykh zakladakh (Problems of informatization of educational process in secondary and higher education institutions) Comp. in sc. and fam., 3, 8 (2013).

[2] O. Gromova Razvitiye informatsionnoy gramotnosti uchashchikhsya v shkol'noy i detskoy biblioteke (The development of information literacy of students in the school and children's library) Libr. school - 1st Sep. 17, 42 (2006)

[3] I. Kolesnikova Novaya gramotnost' i novaya negramotnost' dvadtsat' pervogo stoletiya (New literacy and new illiteracy of the twenty-first century) Cont. Educ: XXI Cent. 2 (2013).

[4] Large Ancient Greek Dictionary. http://slovarus.info/grk.p hp?Id =\% 26\% 23947\%3B\&pg=9. Accessed 27 Sep 2018

[5] New Philosophical Encyclopediahttp://iph.ras.ru/elib/1136 .html Accessed 27 Dec 2019

[6] S. Ivanov Media and information literacy as a complex of basic technologies in lifelong education Comp at sc. and fam. 7. 11 (2014)

[7] L. Familyarskaya Orhanizatsiya osvitn'oho seredovyshcha pislyadyplomnoyi pedahohichnoyi osvity zasobamy khmarnykh servisiv Google (Organization of the educational environment of postgraduate pedagogical education by means of Google cloud services) Inf and inf. techn. in ed. inst. 5-6. 38-44 (2015)

[8] T. Vakalyuk Khmarni tekhnolohiyi v osviti. (Cloud technologies in education) ZHU, 72 (2016)

[9] World Open Educational Resources Congress http://www.unesco.org/new/en/communication-and-inform ation/events/calendar-of-events/events-websites/World-Op en-Educational-Resources-Congress Accessed 7 Aug 2019

[10] S. Kubrak Merezha Internet ta E-mails - vazhlyvi zasoby komunikatsiyi pid chas vyvchennya inozemnykh mov (Internet and E-mails - important means of communication when learning foreign languages) 5. 83-87 (2017)
[11] V. Smirnov, and R. Smirnova Statisticheskaya obrabotka anket, soderzhashchix bal'nye shkaly. (Statistical processing of questionnaires containing point scales) Kostroma, 117-121 (1990) 